\title{
Helga Crane ReConsidered: An Intellectual EXPERIENCE WITH ESSENTIALISM IN QUICKSAND
}

Ammar Abduh M. Aqeeli, College of Arts and Humanities, Jazan University, Saudi Arabia, aaaqeeli83@gmail.com

Original scientific paper

DOI: 10.31902/fll.34.2021.4

UDC: $821.111(73) .09$

\begin{abstract}
The themes of quest for racial identity in Nella Larsen's Quicksand and the protagonist's struggle with dual identity are the most commonly discussed topics in countless critical articles over the past twenty years. However, Larsen's portrayal of Helga Crane's struggle to find an identity as a woman of mixed race serves to demonstrate that her issue is mainly with how society is essentialist. The primary goal of Quicksand is to demonstrate the fluidity of identity. With the challenges that the protagonist faces in the story, Larsen vividly demonstrated that identity is relentlessly changing. The purpose of this paper is to illustrate that the reductionist nature of different forms of essentialism causes many people continuous suffering. In other words, Larsen deploys the mulatto figure as a useful critical tool to explore how society is immersed in essentializing categories of race, class, gender and sexuality.
\end{abstract}

Keywords: mulatto; identity; race; essentialism; prejudice

Nella Larsen portrayed Helga Crane as a mixed girl whose search for happiness and a position in society is characterized by ambivalence about how race, class, gender, as well as religion are perceived by humans. Generally speaking, Helga Crane is portrayed as a mulatto in two worlds defined mainly by race. Clearly, the challenges that she faces in the story make her questions any form of cultural imposition. Her ability to move between two contrasting cultures, despite her struggling experience with issues of belonging, shows her the fluidity of identity. She demonstrates that various identity markers are socially and culturally constructed. However, she is unable to resist the process of formation of identity controlled by society, which leads to her tragic end. Although Helga's suffering throughout the novel propels the idea that she is a stereotypical "tragic mulatto," Larsen used it as a critical strategy in two different ways. First and foremost, to destabilize her society's embrace of essentialist notions of identity. Second, to stop any confusion arises between her personal life and the life of her protagonist. 
Larsen's unhappy and difficult childhood and the problem of race during the time period have drawn a number of critics to compare her life with Helga's. Emily M. Hinnov asserts that Larsen's complex life as a child inspires her to portray Helga's experience as an unhealthy one: "Larsen's own decidedly nonidyllic childhood experience explains Helga's own difficulty in fully welcoming a consciousness of wholeness" (196). Helga's inability to break free of the shackles of race problem and the color line in society makes her seems less intelligent than Larsen. That is not to say that Helga cannot be affected by the negative consequences of racism against colored people, but she is smart and educated enough to resist and find happiness in her life. As explained by George Hutchinson, Helga is a "modern and intelligent" character who "would find some other way out of her predicament" (239). But Larsen chooses to portray her as a victim of her society.

It is important to note that Helga can be easily blamed for falling into the trap of essentialism because she is clearly introduced as an intellectual at the beginning of the novel (Roffman 8). Helga sits "alone in her room" that is full of "bright covers of the books," which she took earlier "from their long shelves" (1). Helga's intellectual faculty is not merely demonstrated through piling up books on shelves, but through her sharp assessment and analysis of the unmistakable flaws of her society. However, despite Helga's awareness of such flaws and her preparation to choose what is good for her, her choices are greatly affected by the social constraints of the time period. According to Erin Chapman, "Helga's story and choices are particular to her, but the circumstances that shaped and constricted them are social and formed through sexual and racial discourse" (145). Helga's intellect sometimes proves inadequate in front of the social forces surrounding her.

This paper reexamines Quicksand against the tendency that confines Helga Crane to the fate of tragic mulatto. ${ }^{1}$ The novel's epigraph from Langston Hughes's poem "Cross" is an apposite quotation for the notion that Helga is a tragic mulatto. However, according to Deborah McDowell, the epigraph is "partially" relevant to the novel (xvii). It covertly makes reference to the issue of fixing or naturalizing individuals' identities. By examining Helga's reaction to essentialism, it becomes clear that Larsen's goal is to create a heroine as a device to criticize her society's adoption of narrower essentialist notions of identities. This paper aligns with other scholarship that tends to demonstrate the complex intersections of race, gender, sexuality, and

\footnotetext{
${ }^{1}$ Several critiques point to this same conclusion. See Hugh M. Gloster 143, Mary V. Dearborn 61-70, Lillie P. Howard 223-233.
} 
class. Quicksand is a representation of a female intellectual who encounters unresolved tension between her personal desires and the expectations of her society. Such expectations are often framed by solid social categories. McDowell, asserts that Larsen portrays Helga as a person who is "physically divided between a desire for sexual fulfillment and a longing for social respectability" rather than a victim of "confusion" created by "mixed racial heritage" (xvii). Helga yearns to be socially accepted without being forced into essentialist models of social groups. Jessica Rabin postulates that "Helga's/Larsen's ideal world would be one which could accommodate flexibility and transitivity instead of insisting that everyone fit into a unitary, essentialist category" (112). However, Helga by her choice plays some roles of fixed identities so that she can be considered socially accepted.

Larsen depicted her protagonist as a biracial woman who is forced by her society to perform different identities. Helga understands that both white and black communities will not understand her identity crisis as she deals with two communities that are deeply involved in defining race and gender as stable categories. On the one hand, she is not accepted by her white family because of her skin color. On the other hand, she has to hide her white identity and to avoid mentioning any association with white people when she desires to socialize with black people. In other words, she is perpetually torn between two diverging worlds, affected by the rigid and monoracial categories created and enforced by society. Helga's ability to perform different identities makes of Quicksand a postmodernist text that treats identity as ambiguous and fluid construct. Although Quicksand demonstrates that identities are not intrinsic, it also emphasizes the effectiveness of temporarily utilizing essentialism to disrupt the fixed binaries of race and gender.

This paper draws upon poststructuralist critique of essentialism, which negates the notion that identities of race, gender, or anything else are immutable. From a poststructuralist perspective, the novel heroine believes that identities are fluid and dynamic. Through her journey for social acceptance, she observes and evaluates the reductive apparatus that reproduce and generalize binary positions of essentialized identities. Echoing African American poststructuralist critics, Helga contends that essentialism from both dominant and subordinate positions can perpetuate oppression. ${ }^{2}$ Within an oppressed social

\footnotetext{
${ }^{2}$ In The Henry Louis Gates, Jr. Reader, Gates criticized the Black Arts movement for attacking "European or Western essentialism ... by asserting an oppositional black of 'neo-African' essentialism” (180). Anthony Appiah discourages defining
} 
group, there is a possibility of oppressed subordinates who do not fit in with its essentialist discourse.

Moreover, Diana Fuss' critique of essentialism informs this paper. She argues that essentialism is an effective tool "that can be deployed ... in the service of idealist and materialist, progressive and reactionary, mythologizing and resistive discourses" (xii). Fuss has bridged the opposition between the poststructuralists critique of essentialism and the use of essentialism by those who have no represented voice. Essentialism can be used as a strategy to resist the negative or reductive constructed designations of race, gender, sexuality, and other social categories. Constructionism survives on essential ideologies that attempt to perpetuate and maintain social hierarchies. According to Fuss, "Constructionism is fundamentally dependent upon essentialism to do its work" (xii). Fuss's argument is important because it helps evaluate Helga's reaction to essentialism. For Helga, essentialism is dangerous in some contexts but helpful and necessary in other contexts.

From the beginning, Helga resents how African Americans are placed in fixed positions that are believed to be dictated by nature to establish a racial hierarchy and to justify white domination. She is disturbed by the speech given by the white preacher at the black institution of Naxos:

And he had said that if all Negroes would only take a leaf out of the book of Naxos and conduct themselves in the manner of Naxos products, there would be no race problem, because Naxos Negroes knew what was expected of them. They had good sense and they had good taste. They knew enough to stay in their places, and that, said the preacher, showed good taste. (3)

For Helga, the root of her identity issue is neither her physical appearance nor her biological existence, but the flaw of a system that reinforces essential differences between races. As part of the social and political realities in America, one might say that black people are inferior by nature to their white counterparts. Ironically, the black audience at Naxos seems to accept its placement by the preacher in a lower rung on the human ladder below whites, which has left Helga with feelings of anger and astonishment.

Helga is critical to the repercussions of adopting the same tools of oppression that are in the hand of the oppressor. Another factor of

race biologically as it reproduces the oppressive practices that African Americans fight against. See The Lies that Bind: Rethinking Identity. 
Helga's identity problem lies in her frustration of her people at Naxos who believe in the fixed and essentialist forms of identities imposed by whites. They attempt to reinforce a homogenized and idealized black identity which eventually leads to suppressing any intragroup differences. The black middle class at Naxos perceives its group as positively pure and it must be maintained from pollution linked to irreligion. The society at Naxos understands religion and its teachings from an essentialist perspective through which certain forms of behavior and manners need to be practiced or avoided in the public realm. For instance, the members of Naxos, particularly women, must adhere to a strict dress code to endorse the idea that gender's fixedness is an eternal truth. Otherwise, anyone who does not abide by such rule is subjected to surveillance and intolerance because he/she acts as an outsider who may endanger the unity of his/her group.

Helga continues to undermine the essentialist binaries that the folks at Naxos internalize from their white oppressor. Ironically, instead of inverting them as a strategic tool for resistance, they adopt what white people think of as appropriate or inappropriate. The school disapproval of her wearing bright-colored clothes and its emphasis on wearing dark ones is a result of its members' internalization of the white gaze. Through its racist essentialism, the white gaze perpetuates the notion that black people are primitive by nature and white people are inherently civilized. In an attempt to redefine black identity, the black uplift rhetoric at Naxos emulates the oppressor's understanding of colors as a means to highlight the essential difference between races. At Naxos, bright colors like "yellow, or green, or red" are "vulgar," and black people should not wear them as they reinforce the idea that black people are from primitive jungle.

Helga realizes that her existence at Naxos brings her resentence rather than happiness because of the way she is treated there. Her dissatisfaction with the place arises from what she sees as a process of instilling immutable characteristics of its community that must be shared by all members: "Enthusiasm, spontaneity, if not actually suppressed, were at least openly regretted as unladylike or ungentlemanly qualities. The place was smug and fat with selfsatisfaction" (4). Helga understands that her gender identity has been reduced to specific qualities that are considered appropriate by the patriarchal culture at the institute. Helga's observation of traditional gender roles at Naxos echoes Butler's argument of performativity of gender. Helga does not preform her gender well, which according to Butler, "initiates a set of punishments both obvious and indirect, and performing it well provides the reassurance that there is an essentialism 
of gender identity after all" (528). Helga finds her gender role at the school a product of identity politics but not a choice of her own free will.

Larsen's depiction of Helga's awareness of gender essentialism at Naxos is magnified when she calls the school a place of "ladies-inmaking" (12). Helga's critique of Miss MacGooden's perception of the school girls' purity is comical. According to Helga, Miss MacGooden' understanding of gender essentialism is extreme: "Miss MacGooden's 'ladyness,' Helga grinned a little as she remembered that one's expressed reason for never having married, or intending to marry" (12). In other words, Miss MacGooden believes that it is against nature, and it is "too repulsive for a lady of delicate" to demonstrate sexual desires even if she is legally married. Miss MacGooden further promotes the Naxos' patriarchal essentialism, which evokes Helga's mockery of her. It is clear for Helga that Naxos prescribes some traits, characteristics and ways of behaving to its female students as innate qualities attributed to woman.

Helga's experience at Naxos grows her awareness of the power of essentialized gender categories perpetuated there, but she is never able to act in ways that are similar to other school members:

She could neither conform, nor be happy in her unconformity. This she saw clearly now, and with cold anger at all the past futile effort. What a waste! How pathetically she had struggled in those first months and with what small success. A lack somewhere. Always she had considered it a lack of understanding on the part of the community, but in her present new revolt she realized that the fault had been partly hers. A lack of acquiescence. She hadn't really wanted to be made over. (7) Helga protests obscuring her different personality as a woman of mixed color. Despite her efforts to be accepted by the community, she successfully avoids falling into the trap of its essentialist agendas as it aggravates her unhappiness and oppresses her. She does not meet the established expectations of her role as a woman. Thus, she is seen as an imperfect member, which triggers her feelings of sadness and alienation.

Helga wants to cultivate a positive identity to prove herself acceptable in the larger community, but she fails due to its belief that identity must be resolved. However, Helga's feelings of failure to be accepted and appreciated by both black and white societies proves her ability to shift and change her identity. Julie Spergel accentuates how Larsen's characters, particularly Helga, are aware of the idea that identity is changing. She notes:

Nella Larsen shows sympathy for the figures in Quicksand and Passing who are unhappily contained in one restrictive identity, and for 
a while, the characters take comfort in having several masks to act behind. There are many different ways of performing race, gender, place, and class - paradoxically - in an effort to legitimize claims to these markers of identity in the first place - proving that none of these alone can be stable indicators of identity, even when, for example they give a sense of belonging and a desire to be part of something bigger than oneself. (259)

Helga resents the rules of society that dictate she either must be black or white. Her criticism of the black middle-class members of Naxos exemplifies her awareness of the danger of promoting racial essentialism, which assumes that identities are stable constructs. Helga expresses the danger and limitations of maintaining notions of authentic identity: "Life had died out of it. It was, Helga decided, now, only a big knife with cruelly shape edges ruthlessly cutting all to a pattern, the white man's pattern" (4). She is critical to the repercussions of adopting the same tools of oppression that are in the hand of the oppressor

Helga believes that the middle-class blacks' call for racial uplifting suppresses and/or denies intragroup differences. In her case, she is not tolerated, not only due to identity issues related to her racial composition, but also to constructed images of sexual orientation:

Too, they felt that the colors were queer; dark purples, royal blues, rich greens, deep reds, in soft, luxurious woolens, or heavy, clinging silks. And trimmings-when Helga used at all-seemed to them odd. Old laces, strange embroideries, dim brocades. Her faultless, slim shoes made them uncomfortable and her small plain hats seemed to them positively indecent. (18)

The Naxos members try to nurture a unitary and positively black-defined identity by assuming the "norms" of "blackness." But the colors and style of Helga's clothes are considered to be outside the norm, which makes her an inferior member within the Naxos community. Sachi Nakachi suggests that "the 'blackness' that the Naxos people assert is nothing but a construction modeled on white middleclass morality" (64). In other words, the Naxos' criticism of Helga's clothes is reminiscent of the middle-class white man's stigmatization of group members who deviate from the norms that are predominately set by heterosexual white male. In other words, black people are as religious as white people, and they both believe that God had created two different genders who are forbidden to practice homosexuality.

Through Helga's pursuit for acceptance by her society and her family, Larsen critiques white America's prohibition of interracial marriage and relationship. For Larsen, its ban of interracial relationships, whether in or outside marriage, is based on racial essentialism, which is 
grounded in the belief that race is a biological or genetic category. When Helga goes to visit her uncle, she is met by his wife whom she feels "latent antagonism in [her] manners" once she knows that Helga is her husband's niece. Mrs. Nilssen responds: "oh, yes! I remember about you now. I'd forgotten for a moment. Well, he isn't exactly your uncle, is he? Your mother wasn't married, was she? I mean, to your father?" (28). Mrs. Nilssen seems indifferent to Helga's biological features as a colormixed girl and to the fact that Helga is a product of illegal interracial marriage.

However, as the novel unfolds, it becomes clear to readers that even a talk about interracial relationships during the time period is considered taboo. Larsen asserts that Helga's story, which she relates to Mrs. Hayes-Rore, her employer, does not exist in a society defined by a racial binary: "The woman felt that the story, dealing as it did with race intermingling and possibly adultery, was beyond definite discussion. For among black people, as among white people, it is tacitly understood that these things are not mentioned - and therefore they do not exit" (39). Larsen also reveals some of Helga's mixed features, which are indicative of a racially mixed parent. In Copenhagen, it is confirmed that Helga is perceived as a "dark" woman or "Den Sorte," meaning black, whose "alien appearance was to most people an astonishment" (73).

For Larsen, how society perceives race as a genetic criterion rather than as a social creation plays an important role in Helga's sense of alienation and misery.

As Helga tastes her position in the black society in Harlem, she realizes that its black members adhere to binary constructions of racial identity as pure and unified. Initially, she is welcomed as a dark-skinned person because she is perceived to be of black origin, and she never reveals her white identity. The narrator notes: "Harlem, teeming black Harlem, had welcomed her and lulled her into something that was, she was certain, peace and contentment" (43). She seems to be content that she finally belongs "somewhere". However, the narrator emphasizes the fact that Helga still feels like an outsider because of what she observes as an irrational advocacy of black racial pride and purity, which jeopardizes her chances of being fully accepted in Harlem. Despite Anne Grey's hypocritical perception of racial pride, Helga understands that her white ancestry could infuriate Anne who hates white people "with a deep and burning hatred" (48).

Helga has to avoid mentioning that her relations are white upon following advice from Hayes-Rore. She knows that the colored people will not understand it and that the whole relations issue is her own problem. The protagonist has to contend with keeping half of her 
identity to herself despite being physically similar to those around her. She hides the past contribution of the white folk in her life as it had been full of grief and shame. Helga thinks of white people as "sinister" folks who assume racial difference as the biological inferiority of dark-skinned people. Because of her racial markers, Helga believes that her "birthright" was stolen by white people (45). As an individual of color, she believes that white people have stolen her right to be born free and equal in dignity and rights. Helga has no choice but to hide her past because she thinks some blacks in Harlem are as preoccupied with essentialist reasoning about race as white people are.

Indeed, Helga finds in her friend Anne Grey an unapologetic and contradictory obsession with the race problem. She believes that African Americans must be devoted to racial uplift to prove that they are worthy of respect. Her calls for racial progress blur the line between racial awareness and racial essentialism. One of her ways to lift black people to a higher standard of life is intragroup unity. In her reaction to Audrey Denney's breaking of racial barriers, Anne believes that colored people like Audrey must be excluded from the black community:

It's the principle of the thing that I object to. You can't get round the fact that her behavior is outrageous, treacherous, in fact. That's what's the matter with the Negro race. They won't stick together. She certainly ought to be ostracized. I've nothing but contempt for her, as has every other self-respecting Negro. (61)

Anne creates a standard of blackness that is narrowly framed within adversarial relations between whites and black people. She yearns to see a homogenous black community that is defined by essentialist markers such as racial purity. Reminiscent of black racial essentialists, Anne and her guests at the party wish to ostracize Audrey as she poses a threat to their racial identity and heritage.

In Harlem, Helga believes that she finally belongs to there, but she is met with disappointment as her sense of belonging might be questioned. Her understanding of the reductionist nature of the ideology of black consciousness that she observes in Harlem distances her from what she once believes as home. Helga will never find happiness and satisfaction in any society that treats its groups as stable or homogeneous entities. After one year in Harlem, Helga feels as an outsider, which grows her feelings of restlessness and discontent:

Somewhere, within her, in a deep recess, crouched discontent. She began to lose confidence in the fullness of her life, the glow began to fade from her conception of it. As the days multiplied, her need of something, something vaguely familiar, but which she could not 
put a name to and hold for definite examination, became almost intolerable. She went through moments of overwhelming anguish. She felt shut in, trapped. (47)

For Larsen, Helga's suffering is a wake-up call for contemporary societies where identity crisis has become one of the principal challenges. Such difficulties lie in the fact that societies cannot comprehend the elastic nature of identity.

After her disappointment in Harlem, Helga decides to move to Denmark "where there were no negroes, no problems, no prejudice" (55). In the beginning, Helga believes that race problem in Denmark is not as big as the one in the United States. According to Rikke Andreassen and Kathrine Vitus, Helga's mixed heritage does not cause her as much trouble in Denmark as it does in the US because "interracial marriages were never forbidden legally in Denmark, as they were in several states in the USA" (100). Although Larsen makes such a claim true throughout Helga's journey in Copenhagen, it is questioned on her last days in Denmark. Of course, Helga receives a better treatment by her Danish family, and she believes that America is worse when it comes to treating black people when, once, she thinks about going back: "Go back to America, where they hated Negroes! To America, where Negroes were not people ... To America, where if one had Negro blood, one mustn't expect money, education, or sometimes, even work whereby one might earn bread" (82). However, she faces the issues of classifications and racial essentialism that are usually exercised by colonial powers.

In Copenhagen, Helga encounters another form of essentialism that places her in a whole new binary category. She meets Axel Olsen, a Danish artist, who falls in love with and expresses his feelings to her: "I, poor artist that I am, cannot hold out against the deliberate lure of you. You disturb me ... You creep into my brain and madden me" (86). He proposes marriage to her, but she rejects because she suspects that he is not sincere in his love, and she thinks that it may turn into hatred of "all dark people" Her suspicion stems from the way Olsen treats her. Olsen positions Helga as an exotic other from the far East who is also seen as an object of spectacle. He suggests for Helga colorful clothes from the East that he thinks are suitable for her skin color:

There were batik dresses in which mingled indigo, orange, green, vermilion, and black; dresses of velvet and chiffon in screaming colors; blood-red, sulphur-yellow, sea-green; and one black and white thing in striking combination. (55) 
Helga is aware that marrying Olsen would give him more chance to fulfill his white colonial gaze, which treats its subordinates as an amusing exhibition of exotic and primitive objects. Yemisi Jimoh asserts that Helga's refusal to marry Olsen is because she "recognizes in his proposal the suggestion of their marriage as the fulfillment of a certain primitivist desire" (74). Earlier, she rebukes Olsen's portrait of her as "some disgusting sensual creature" (89). For Helga, Olsen interest in her might turn into a perpetuation of the racial essentialism that European colonialism has historically assigned to women of color. In an essentialist sense, Olsen perceives Helga as racially Other through which he plays the role of a European colonialist controlling and exploiting a nonEuropean subject. As postulated by Nackachi, Olsen's choice of Helga's dresses is an application of "white colonialist strategy of differentiating the colonial other. He needs to confine Helga's mulatto body into nonWestern space in order to prove his power over her" (73). As much as Helga denounces essentialism, she deploys it to strategically resist Olsen's controlling attitudes.

Echoing Fuss's critique of essentialism, Helga believes that antiessentialism is always good as it deconstructs oppressive discourses and assumptions about superior and inferior categories of race, gender, class, and sexuality. However, Larsen warns against "efforts by hegemonic groups to use essentialism as a political tool waged against less powerful groups" (40). Thus, she enables Helga to "activate" or "deploy" essentialism to resist the colonial hegemonic stereotypes of race and sex that Olsen constructed about her. Helga rebukes Olsen for asking her to be his mistress believing that he treats her as colonial possession that is reminiscent of the colonial white male desire for a black female body: "I'm not for sale. Not to you. Not to any white man" (87). Helga resists Olsen's request by providing him with an idealized image of her race: "Because, Herr Olsen, in my country the men, of my race, at least, don't make such suggestions to decent girls" (86). In her case, Helga does not fall into the trap of essentialism, rather she intentionally and temporarily deploys it to resist another form of essentialism.

Helga as an intellectual does not necessarily mean that all men of her race are idealized as being respectful and courteous to women, especially black women. On the surface, she seems to embrace a "recourse to an ontology which stands outside the sphere of cultural influence and cultural change" (Fuss 3). In other words, she appears to embrace an ontological position through her comparison of the moral status of white and black men. According to Helga, black men are more moral than white men. Her statement may sound radical, but such 
radicality, according to Fuss, "depends ... on who is utilizing it, how it is deployed, and where its effects are concentrated" (20). In her case, Helga utilizes essentialism to emphasize the immorality of stereotypical depictions of black women by white society as exotic objects of sexual desire. Had she thought that all black men are decent by nature, especially when it comes to their treatment of women, she would have never criticized the patriarchal practices that she observes earlier at the Naxos.

By the end of the novel, Helga might be blamed or praised for conforming to the patriarchal and religious expectations that are dominant in the rural South. Those who support essentialist blackness and its association with chauvinistic gender roles would hail Helga's shift to a domestic sphere. Larsen's reticent engagement with the subject of sexuality in the novel and her choice to confine it within the context of marriage render her work praise from black middle-class intellectuals. For critics like W. E. B. Du Bois, Quicksand is "a fine, thoughtful and courageous piece of work" as it does not perpetuate the "nastiness" of portraying black women as primitive sexual objects (qtd. in Hutchinson 284). Du Bois considers Larsen's work as an exemplary writing that does not follow the rules prescribed by Carl Van Vechten, a white patron of the Harlem Renaissance, which are adopted by a number of black writers.

Du Bois's praise of Quicksand stems from his desire to subsume African Americans into a unitary category through which a better image of them is agreed upon in order to negate the stereotypes constructed by their oppressor about their race. He called for black artists to create positive images of African Americans in their works for the purpose of racial uplift. One of the ways that Du Bois supported this idea was by providing "cleaner" representations of black people, particularly women, who had been subject to moral damnation throughout history. However, Du Bois's vision to see blacks gain acceptance in mainstream America through black intellectuals would reinforce intra-racial hierarchy. Ironically, as Du Bois attempted to fight the racial hierarchy established by racial essentialism, he would create a similar hierarchy within the black race.

For Du Bois, the difference between an intellectual black protagonist and an uneducated black lower-class female character was obvious. In other words, the former is educated and could easily fit into the mainstream society, while the latter is poor and uneducated and could represent negative images of black women. Du Bois thought that Quicksand would fit in with his program of racial and moral uplift of black people. However, as the whole novel is a relentless critique of 
different forms of essentialism, it also questions how black intellectuals promoted racial uplift ideology. Those intellectuals believed that black middle class had the obligation to lead the masses. Such belief perpetuated biological essentialism in the form of "biosocial version of uplift" (English 41). As postulated by Daylanne K. English, "Talented Tenth" by Du Bois is an exemplary text that "is identified with an explicitly biological superiority" (41). Thus, the middle-class and intellectual Helga is superior to a black prostitute on Harlem street.

However, in Quicksand, Larsen veered away from representing an ideology of racial uplift that promotes intra-racial class stratification. Although all Larsen's main characters in the novel are from middle-class backgrounds, and the lower class is underrepresented if represented at all, she definitely demonstrated a covert rejection of Du Bois's hierarchical essentialism. For Larsen, being a middle-class intellectual is not hereditary and, therefore, not fixed, but rather can be fluid and contextual. She shook the supposed immutability of the middle-class moral and intellectual superiority when Helga is mistaken as a prostitute. The narrator points out that "a few men, both white and black, offered her money, but the price of the money was too dear. Helga Crane did not feel inclined to pay it" (34). There are no essential biological features that make Helga morally and socially notable by strangers unless they know who she really is.

As far as Helga's choice of playing a maternal role for the rest of her life with a Southern preacher, it is evident that Larsen intended to demonstrate the racial uplift essentialist reduction of women. The religious racial uplift in her husband black church limits woman's freedom of choice with respect to her reproductive right. Although Helga and other churchwomen are overwhelmingly present in the text as important role players in the discourse of racial uplift, their efforts are confined to the domestic sphere. Helga observes that the church dedication to racial uplift adopts certain white cultural norms to achieve black respectability in mainstream America. The emphasis on the traditional role of women as mothers is comparable to the essentialist belief of mainstream culture that women are biologically prepared to bear children. Helga is no longer biologically capable of giving birth to more children, nor is she free to choose not to be. She becomes ill, renounces religion and the black church, and eventually dies.

Throughout the novel, Helga makes strenuous effort to resist her society's embrace of essentialist notions of identity. Despite her efforts, she ends up caught in unsatisfying homemaker role. She ends up lured discontentedly in a housewife role with no room for escape. 
The circumstance surrounding this expedition is not peculiar to Helga's situation of being a biracial woman. Identity is relentlessly changing, and human experience calls that people restructure their identities based on experiences, environment, social perspectives and situations. With insightful and critical consideration of the challenges that the protagonist goes through in the novel, contemporary societies can consider tolerance as an effective tool for alleviating the suffering of those in the search of their identities.

Larsen is more concerned with criticizing a suffocating society, which assumes that some of its members have an unchanging essence inside their groups. Helga's problem is not her race neither her difficult childhood. Her problem lies in the fact that she faces a society that divides its members into superior and inferior categories, which proves her weakness to resist such process. Helga is well-educated and has the mental capacity to perceive that her society is run by a system that reinforces essential differences between races through which different categories of identities are maintained. She internalizes some of these categories as a means of resistance. She sometimes demonstrates an ambivalence to what constitutes as societal constructed forms of identity. Although Helga is aware that identity is constructed rather than genetically fixed, she trapped herself into a process of self-hating because of her race. Larsen can take Helga out of this trap, but her intent was to demonstrate the negative consequences of internalizing the attitudes of the dominant society towards her race. Larsen uses Helga as a tool to criticize society as she eventually falls into the trap of essentialism practiced by society.

\section{Works Cited}

Andreassen, Rikke, and Kathrine Vitus. Affectivity and Race: Studies from Nordic Contexts. Routledge, 2016.

Appiah, Kwame A. The Lies That Bind: Rethinking Identity. Liveright Publishing, 2018.

Butler, Judith. "Performative Acts and Gender Constitution: An Essay in Phenomenology and Feminist Theory." Theatre Journal, vol. 40, no. 4, Dec. 1988, pp. 519-531.

Chapman, Erin D. Prove It on Me: New Negroes, Sex, and Popular Culture in the 1920s. Oxford UP, 2012.

Dearborn, Mary V. "Black Women Authors and the Harlem Renaissance." Pocahontas's Daughters: Gender and Ethnicity in American Culture, Oxford UP, 1986, pp. 61-70.

English, Daylanne K. Unnatural Selections: Eugenics in American Modernism and the Harlem Renaissance. $U$ of North Carolina P, 2005. 
Fuss, Diana. Essentially Speaking: Feminism, Nature and Difference. Routledge, 1989.

Gates, Henry L. The Henry Louis Gates, Jr. Reader. Hachette UK, 2012.

Gloster, Hugh M. Negro Voices in American Fiction. U of North Carolina Press, 1948.

Hinnov, Emily M. Encountering Choran Community: Literary Modernism, Visual Culture, and Political Aesthetics in the Interwar Years. Susquehanna UP, 2009.

Howard, Lillie P. "'A Lack Somewhere': Nella Larsen's Quicksand and the Harlem Renaissance." Harlem Renaissance Re-examined, edited by Victor A. Kramer, AMS Press, 1987, pp. 223-233.

Hutchinson, George. In Search of Nella Larsen: A Biography of the Color Line. Harvard UP, 2009.

Jimoh, A. Y. Spiritual, Blues, and Jazz People in African American Fiction: Living in Paradox. U of Tennessee P, 2002.

Larsen, Nella. Quicksand; And, Passing. Rutgers UP, 1986.

McDowell, Deborah E. "Introduction." Quicksand ; And, Passing, Rutgers UP, 1986, pp. ix- $\quad$ xxxii.

Nakachi, Sachi. Mixed-Race Identity Politics in Nella Larsen and Winnifred Eaton (Onoto Watanna). 2001. Ohio University, PhD Dissertation. ProQuest Dissertations and Theses. $\quad$ Accessed 1 Sept. 2019.

Rabin, Jessica. Surviving the Crossing: (Im)migration, Ethnicity, and Gender in Willa Cather, Gertrude Stein, and Nella Larsen. Routledge, 2005.

Roffman, Karin. From the Modernist Annex: American Women Writers in Museums and Libraries. $U$ of Alabama P, 2010.

Spergel, Julie. "Questioning Racial Passing as a Form of Cultural Lying." Cultures of Lying: Theories and Practice of Lying in Society, Literature, and Film, edited by Jochen Mecke, Galda \& Wilch, 2007, pp. 241-260.

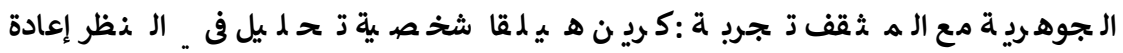

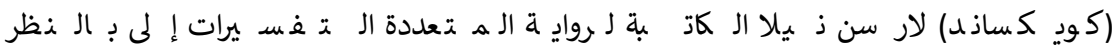

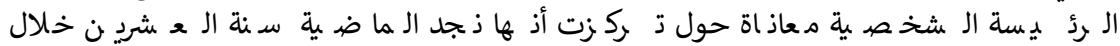

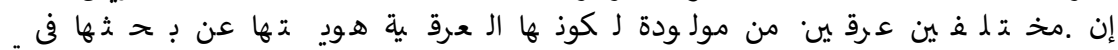

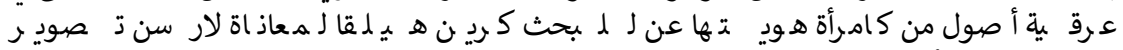

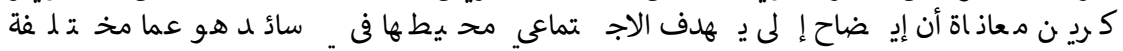

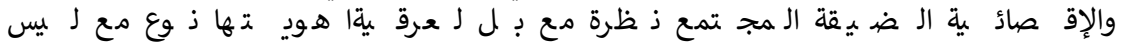

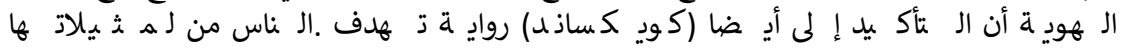

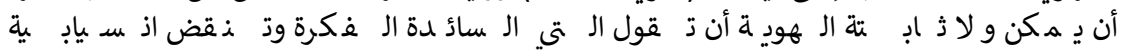

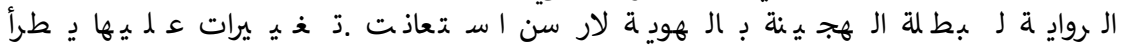

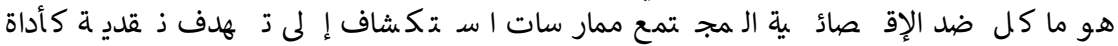

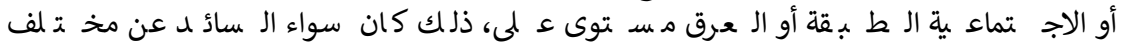

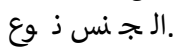

ال تح يز - ال جوهريدة - ال عرق - ال هوي ة - هج ين :المه فف تاحية ال كلمات 